\title{
PERAN PENDIDIKAN DAN PELATIHAN DALAM MEMODERASI PENGARUH SISTEM KOMPUTERISASI DAN KOMPETENSI PENGGUNA PADA KINERJA SIA
}

\author{
I Gusti Ngurah Ariyanatha ${ }^{1}$ \\ Ketut Alit Suardana ${ }^{2}$ \\ ${ }^{1,2}$ Fakultas Ekonomi dan Bisnis Universitas Udayana, Bali, Indonesia \\ e-mail: ignariyanatha@gmail.com
}

\begin{abstract}
The Role of Education and Training in Moderating the Effects of Computerized Systems and User Competence on SIA Performance. Revenue Agency has an important and strategic role to increase regional income in Bali Province. Therefore, it needs to be supported by an effective and efficient accounting information system. The purpose of this study was to obtain empirical evidence of the influence of computerized systems and user competencies on the performance of accounting information systems and to obtain empirical evidence of the role of education and training in moderating the influence of computerized systems and user competencies on the performance of accounting information systems at Bapenda in Bali Province. The population in this study were all SIA users in Bapenda, Bali Province. The method of determining the sample using a saturated sampling technique, so that the entire population of 42 employees is used as the research sample. The analysis technique used is Moderated Regression Analysis (MRA).
\end{abstract}

Keywords: computerized system, user competence, education and training, SIA performance.

\begin{abstract}
Abstrak: Peran Pendidikan Dan Pelatihan Dalam Memoderasi Pengaruh Sistem Komputerisasi Dan Kompetensi Pengguna Pada Kinerja SIA. Badan Pendapatan memiliki peranan penting dan strategis untuk meningkatkan pendapatan daerah Provinsi Bali. Oleh karena itu perlu didukung dengan sistem informasi akuntasi yang efektif dan efisien. Tujuan penelitian ini adalah untuk memperoleh bukti empiris pengaruh sistem komputerisasi dan kompetensi pengguna terhadap kinerja sistem informasi akuntansi serta untuk memperoleh bukti empiris peran pendidikan dan pelatihan dalam memoderasi pengaruh sistem komputerisasi dan kompetensi pengguna terhadap kinerja sistem informasi akuntansi pada Bapenda Provinsi Bali. Populasi dalam penelitian ini adalah seluruh pengguna SIA di Bapenda Provinsi Bali. Metode penentuan sampel menggunakan teknik sampling jenuh, sehingga seluruh populasi yaitu sebanyak 42 orang pegawai digunakan sebagai sampel penelitian. Teknik analisis yang digunakan adalah Moderated Regression Analysis (MRA).
\end{abstract}

Kata kunci: sistem komputerisasi, kompetensi pengguna, pendidikan dan pelatihan, kinerja SIA. 


\section{PENDAHULUAN}

Informasi menjadi salah satu kebutuhan yang penting bagi setiap kalangan untuk dapat melakukan dan melanjutkan berbagai bentuk kegiatannya. Pengguna informasi akan dimudahkan jika infomasi yang didapatkannya tepat, akurat, dan relevan. Suatu organisasi atau perusahaan dalam menunjukan keunggulannya perlu memperhatikan informasi, karena merupakan hal yang penting dalam memenangkan persaingan bisnis terutama informasi keuangan. Pengembangan sistem informasi memerlukan suatu perencanaan dan implementasi yang hati-hati, guna menghindari adanya penolakan terhadap sistem yang dikembangkan (resistance to change).

Sistem informasi Akuntansi (SIA) merupakan kumpulan sumber daya manusia yang bertanggung jawab untuk mengolah data keuangan menjadi informasi atau laporan keuangan yang ditujukan kepada pihak internal dan eksternal perusahaan (Prabowo, 2013). Ives et al., (1983) menyatakan bahwa kepuasan pengguna sistem menunjukkan seberapa jauh pengguna puas dan percaya sistem informasi yang disediakan untuk memenuhi kebutuhan mereka. Semakin tinggi tingkat kepuasaan pengguna terhadap sistem informasi akuntansi yang dioperasikan maka semakin tinggi kinerja dari sistem informasi akuntansi tersebut.

Penggunaan sistem informasi akuntansi dapat diaplikasikan pada perusahaan, organisasi, maupun instansi. Salah satu instansi khususnya instansi pemerintah yang menggunakan sistem informasi akuntansi adalah Badan Pendapatan Provinsi Bali atau yang dikenal dengan sebutan Bapenda Provinsi Bali. Bapenda Provinsi Bali adalah organisasi yang berada di bawah pemerintah provinsi Bali yang memiliki tanggung jawab dalam pemungutan pendapatan daerah melalui pengkoordinasian dan pemungutan pajak, retribusi, bagi hasil pajak, dana perimbangan, dan lain sebagainya. Bapenda Provinsi Bali merupakan salah satu pelayanan yang diberikan oleh pemerintah guna meningkatkan pendapatan daerah Provinsi Bali. Tujuan dari
Bapenda Provinsi Bali, yaitu : 1) Mewujudkan kebijakan teknis bidang Pendapatan Asli Daerah (PAD); 2) Meningkatkan kemampuan sumber daya aparatur pemerintah dalam bidang PAD; 3) Memberdayakan potensi sumbersumber PAD dengan tujuan peningkatan PAD serta sasarannya adalah meningkatnya potensi sumber-sumber PAD dan meningkatnya pengelolaan pemungutan PAD.

Memperhatikan tujuan dari Bapenda Provinsi Bali ternyata Badan Pendapatan memiliki peranan penting dan strategis untuk meningkatkan pendapatan daerah Provinsi Bali. Oleh karena itu perlu didukung dengan sistem informasi akuntasi yang berfungsi untuk memperoleh data atau hasil yang nantinya akan digunakan untuk mengukur seberapa besar pendapatan yang mampu dihasilkan oleh masyarakat khususnya di Bali dalam membantu Pemerintah guna menyelenggarakan sebagian tugas umum pemerintahan dan pembangunan dibidang pendapatan daerah. Oleh karena itu sangat pentingnya sistem informasi akuntansi ini diterapkan dengan efektif dan efisien.

Sistem Informasi yang digunakan oleh Bapenda Provinsi Bali adalah Sistem Informasi Pengelolaan Keuangan Daerah (SIPKD). Sistem SIPKD adalah aplikasi terpadu yang dipergunakan sebagai alat bantu pemerintah daerah yang digunakan meningkatkan efektifitas implementasi dari berbagai regulasi bidang pengelolaan keuangan daerah yang berdasarkan pada asas efesiensi, ekonomis, efektif, transparan, akuntabel dan auditable. Aplikasi ini juga merupakan salah satu manifestasi aksi nyata fasilitasi dari Kementerian Dalam Negeri kepada pemerintah daerah dalam bidang pengelolaan keuangan daerah, dalam rangka penguatan persamaan persepsi sistem dan prosedur pengelolaan keuangan daerah dalam penginterpretasian dan pengimplementasian berbagai peraturan perundang-undangan.

Bagi pemerintah daerah yang telah ditetapkan sebagai daerah berbasis implementasi atau berminat mengimplementasikan aplikasi SIPKD akan diberikan pelatihan intensif mengenai cara 
menggunakan, baik secara penggunaan maupun pemeliharaan dan bagi pemerintah daerah yang telah menggunakan aplikasi lain selain aplikasi SIPKD, akan dibantu untuk melakukan semua tahapan terkait dengan proses migrasi tersebut. Adanya SIPKD sebagai sistem informasi akuntansi yang digunakan oleh Bapenda akan membantu dalam organisasi tersebut dalam menjalankan tugas-tugasnya sehingga akan tercapainya misi dari organiasi tersebut. Tercapainya misi dari setiap organisasi dapat dilihat dari kinerja sistem yang digunakan.

Banyak kasus terjadi dimana masih terdapat kendala dalam Penerapan SIPKD seperti diantaranya sumber daya manusia yang kurang, kapasitas memori dalam server yang kurang cukup, salah penginputan data, salah input kode transaksi, adanya gangguan yang disebabkan terjadinya sistem yang eror, mesin yang bermasalah. Selain itu kendala juga terletak pada sistem SIMDA yang belum dapat terintegrasi dengan SIPKD sehingga harus dilakukan pencatatan double entry. Hal tersebut mengakibatkan laporan yang diinginkan tidak bisa cepat didapatkan, sehingga diperlukan maping terlebih dahulu yang dilakukan oleh Badan Pengelolaan Keuangan dan Aset Daerah (BPKAD) kantor Gubernur. Kendala lainnya adalah adanya keterlambatan dalam proses pencatatan laporan operasional (LO) karena sistem yang mencatat persesediaan barang pakai habis tidak terintegrasi dengan SIPKD.

Tujuan pokok diadakannya penilaian terhadap kinerja adalah untuk memotivasi karyawan dalam mencapai sasaran organisasi dan dalam mematuhi standar perilaku yang telah ditetapkan sebelumnya agar membuahkan tindakan dan hasil yang diinginkan. Kinerja Sistem informasi akuntansi dapat dipengaruhi oleh beberapa faktor, yaitu sistem komputerisasi yang digunakan, keterlibatan pengguna, kompetensi pengguna, kemampuan pengguna sistem informasi, dan ketentuan pelatihan dan pendidikan pengguna sistem informasi. Fong (2002) dalam penelitiannya menyebutkan delapan faktor yang digunakan dalam pengukuran kinerja SIA, yaitu keterlibatan pengguna dalam pengembangan sistem, kemampuan teknik personal sistem informasi, ukuran organisasi, dukungan manajemen puncak, formalisasi pengembangan sistem informasi, program pelatihan dan pendidikan pengguna, keberadaan dewan pengarah sistem informasi dan lokasi dari departemen sistem informasi.

Menurut Arif (2015) dalam penelitiannya menunjukkan bahwa variabel kemampuan teknik personal, dan program pelatihan dan pendidikan berpengaruh positif terhadap kinerja sistem informasi akuntansi. Menurut Kharisma dan Juliarsa (2017) dalam penelitiannya pelatihan dan pendidikan pengguna tidak berpengaruh terhadap kinerja sistem informasi akuntansi sedangkan kemampuan pengguna berpengaruh positif dan signifikan terhadap kinerja sistem informasi akuntansi. Syintia (2017) dalam penelitiannya mendapatkan hasil bahwa program pelatihan pengguna mempengaruhi kinerja sistem informasi akuntansi. Immelda (2015) dalam penelitiannya mendapatkan hasil bahwa variabel kemampuan pemakai sistem informasi, serta program pelatihan dan pendidikan pemakai sistem informasi berpengaruh secara signifikan terhadap kinerja sistem informasi akuntansi.

Daryani (2013) dalam penelitiannya mendapatkan hasil bahwa kemampuan teknik personal, serta pelatihan dan pendidikan pengguna berpengaruh terhadap kinerja SIA. Galang (2014) mendapatkan hasil bahwa program pelatihan dan pendidikan yang berpengaruh positif terhadap kinerja SIA, sedangkan kemampuan teknik personal tidak berpengaruh positif dan signifikan terhadap kinerja SIA.

Berdasarkan kajian penelitian terdahulu yang sudah dipaparkan, dapat diketahui bahwa terdapat beberapa perbedaan hasil penelitian sebelumnya, sehingga penulis tertarik untuk melakukan penelitian kembali dengan menggunakan beberapa faktor yang berpengaruh terhadap kinerja SIA diantaranya sistem komputerisasi, kompetensi atau kemampuan pengguna, serta pendidikan dan pelatihan yang dalam penelitian ini akan 
menjadi variabel moderasi. Pengembangan sistem akuntansi yang terkomputerisasi memerlukan suatu perencanaan dan pengimplementasian yang hati-hati, untuk menghindari adanya penolakan terhadap sistem yang dikembangkan. Karena perubahan sistem dari sistem manual ke sistem terkomputerisasi, tidak hanya menyangkut perubahan teknologi tetapi juga perilaku dan organisasional. Jika organisasi mampu mengaplikasikan dan mengembangkan sistem yang terkomputerisasi dengan baik, maka diharapakan akan mampu menggunakan sistem informasi dengan lebih baik, sehingga akan dapat meningkatkan kinerja SIA dengan lebih optimal.

Kompetensi dan kemampuan personal yang tinggi akan memacu pengguna untuk memakai sistem informasi akuntansi, sehingga kinerja sistem informasi akuntansi menjadi lebih efektif. Pemakai sistem informasi yang memiliki teknik baik yang berasal dari pendidikan yang pernah ditempuh atau dari pengalaman menggunakan sistem akan meningkatkan kepuasan dalam menggunakan sistem informasi akuntansi. Kusumastuti dan Irwandi (2012) menyatakan bahwa kemampuan teknik pengguna merupakan rata-rata pendidikan atau tingkat pengalaman dari seseorang. Pengguna sistem informasi merupakan fokus yang penting berkaitan dengan efektifitas sistem informasi, karena pengguna sistem informasi lebih banyak mengetahui permasalahan yang terjadi dilapangan. Keberhasilan suatu pengembangan sistem informasi tidak hanya ditentukan oleh kecanggihan sistem tersebut tetapi ditentukan oleh kesesuaiannya dengan para pengguna sistem tersebut.

Pendidikan dan pelatihan personal digunakan sebagai variabel moderasi, selain karena variabel ini mengacu pada teori Technology Acceptance Model (TAM). Teori TAM merupakan suatu teori terkait mengenai sistem informasi yang memuat model mengenai sikap individu untuk menerima dan menggunakan teknologi. Teori Technology Acceptance Model (TAM) menjelaskan bahwa terdapat dua faktor yang memengaruhi perilaku personal untuk menerima dan menggunakan teknologi. Dua faktor tersebut adalah kemanfaatan dan kemudahan dalam penggunaan teknologi (Surendran, 2012). Berdasarkan teori ini menggambarkan bahwa pendidikan dan pelatihan perlu untuk diikuti oleh pengguna SIA karena pendidikan dan pelatihan dapat meningkatkan pemahaman individu sehingga individu memahami manfaat yang diberikan atas penggunaan SIA tersebut dan memudahkan individu dalam penggunaannya.

Pendidikan dan pelatihan perlu untuk diadakan, mengingat teknologi dan sistem yang terkomputerisasi berkembang dengan sangat cepat yang menyebabkan terjadinya perubahan-perubahan setiap waktu. Pendidikan dan pelatihan penting untuk meningkatkan kompetensi personal dalam penggunaan SIA, dan dari hal ini diharapkan akan mampu meningkatkan kinerja SIA sehingga dapat memberikan dampak positif bagi perusahaan/organisasi/instansi dan personal karyawan.

Penelitian yang akan dilakukan memiliki perbedaan dengan peneliti sebelumnya, yaitu lokasi penelitian dalam penelitian ini akan dilakukan pada Bapenda Provinsi Bali. Maka dari itu berdasarkan latar belakang masalah di atas, maka penulis tertarik untuk mengadakan penelitian dengan judul "Peran Pendidikan dan Pelatihan dalam Memoderasi Pengaruh Sistem Komputerisasi dan Kompetensi Pengguna Pada Kinerja SIA". Berdasarkan uraian latar belakang di atas, maka rumusan masalah dalam penelitian ini adalah : 1) Apakah sistem komputerisasi dan kompetensi pengguna berpengaruh pada kinerja sistem informasi akuntansi di Bapenda Provinsi Bali ?; 2) Apakah pendidikan dan pelatihan memoderasi pengaruh sistem komputerisasi dan kompetensi pengguna terhadap kinerja sistem informasi akuntansi pada Bapenda Provinsi Bali ?

Kajian pustaka dalam penelitian ini adalah Technology Acceptance Model (TAM) dan Human Resources Information System. TAM menawarkan sebuah teori sebagai landasan untuk mempelajari dan memahami 
perilaku pengguna dalam menerima dan menggunakan sisteminformasi.TAMbertujuan untuk menjelaskan dan memperkirakan penerimaan (acceptance) pengguna terhadap suatu sistem informasi. TAM menyediakan suatu basis teoritis untuk mengetahui faktorfaktor yang mempengaruhi penerimaan terhadap suatu teknologi dalam suatu organisasi. Human Resources Information System merupakan sebuah sistem sociotechnical yang terintegrasi dimana memiliki tujuan untuk mengumpulkan, menyimpan dan menganalisa informasi yang terkait dengan departemen sumber daya manusia didalam organisasi yang menggabungkan hardware komputer dan aplikasi, dimana didalamnya terdapat manusia, kebijakan - kebijakan, prosedur dan data yang dibutuhkan untuk mengelola fungsi sumber daya manusia.

Secara sistematis, kerangka berpikir pada penelitian ini dapat dilihat pada Gambar 1 sebagai berikut.

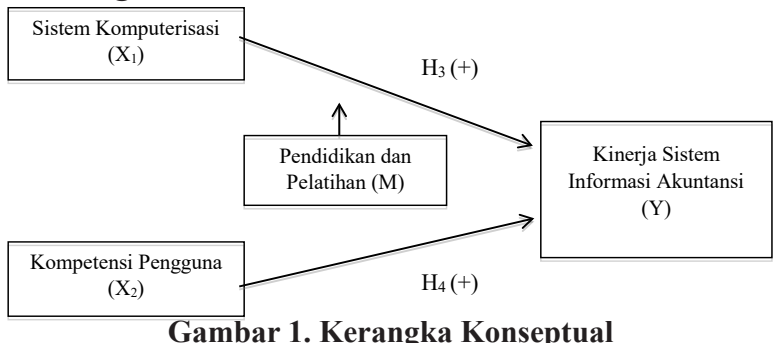

Pengembangan sistem akuntansi yang terkomputerisasi memerlukan suatu perencanaan dan pengimplementasian yang hati-hati, untuk menghindari adanya penolakan terhadap sistem yang dikembangkan karena perubahan sistem dari sistem manual ke sistem terkomputerisasi, tidak hanya menyangkut perubahan teknologi tetapi juga perilaku dan organisasional. Jika organisasi mampu mengaplikasikan dan mengembangkan sistem yang terkomputerisasi dengan baik, maka diharapakan akan mampu menggunakan sistem informasi dengan lebih baik, sehingga akan dapat meningkatkan kinerja SIA dengan lebih optimal.

Hasnidar (2016) mendapatkan hasil penelitian yaitu sistem informasi akuntansi berbasis komputer berpengaruh positif namun tidak siknifikan terhadap kualitas laporan keuangan pemerintah daerah. Hasil penelitian ini menunjukkan bahwa dengan menerapkan sistem informasi akuntansi yang efektif dan efisien, penerapan sistem pengendalian internal pemerintahan yang memiliki kompetensi dalam pengelolaan keuangan daerah serta penerapan akrual basis yang baik akan mampu meningkatkan kualitas laporan keuangan pemerintah daerah.

Fitriyani dan Lismawati (2014) memperoleh hasil penelitian yaitu tidak terdapat pengaruh signifikan penggunaan teknologi informasiterhadap kualitas informasi akuntansi, tidak terdapat pula pengaruh signifikan penggunaan teknologi informasi terhadap kualitas informasi akuntansi, serta tidak terdapat pengaruh signifikan intensitas pemakaian terhadap kualitas informasi akuntansi. Widiastuti (2015) menerangkan bahwa dengan perkembangan jaman dan teknologi masa kini, sistem informasi akuntansi berbasis manual/tradisional sudah mulai ditinggalkan. Perusahaan sudah mulai beralih pada pemakaian sistem informasi akuntansi yang berbasis komputer, karena dianggap lebih cepat, tepat, dan akurat dalam menyajikan suatu informasi berupa laporan keuangan yang dibutuhkan oleh pihak yang berkepentingan dalam rangka mencapai tujuan perusahaan. Berdasarkan uraian diatas, maka hipotesis satu dinyatakan sebagai berikut:

H1: Penghindaran pajak berpengaruh positif pada nilai perusahaan

Kompetensi/kemampuan pengguna sistem informasi mempunyai peranan yang penting dalam pengembangan sistem informasi guna menciptakan laporan perencanaan yang akurat sehingga setiap karyawan harus mampu menguasai penggunaan sistem berbasis komputer agar dapat memproses sejumlah transaksi dengan cepat dan terintegrasi, menghasilkan laporan tepat waktu dalam berbagai bentuk, serta dapat menjadi alat bantu keputusan. apabila pengguna sistem informasi tersebut tidak memiliki kemampuan dalam mengoperasikan sistem tersebut maka sistem informasi tersebut tidak akan beroperasi secara maksismal.

Kharisma dan Juliarsa (2017) dalam penelitiannya mendapatkan hasil bahwa 
kemampuan pengguna berpengaruh terhadap kinerja sistem informasi akuntansi. Penelitian yang dilakukan oleh Choe (1996) dan Suryawarman (2013) menemukan bahwa kemampuan teknik personal sistem informasi akuntansi berpengaruh terhadap kinerja sistem informasi akuntansi. Yunita, dkk (2016) memperoleh hasil penelitian bahwa kompetensi pengguna berpengaruh signifikan terhadap kinerja sistem informasi akuntansi. Supriyati (2015) mendapatkan hasil penelitian yaitu kompetensi user, keandalan software dan keandalan database secara simultan berpengaruh positif terhadap kualitas informasi akuntansi. Astria, dkk (2017) menerangkan bahwa kompetensi pengguna berpengaruh signifikan terhadap kualitas sistem informasi akuntansi. Berdasarkan uraian dari penelitianpenelitian terdahulu, maka hipotesis dua dinyatakan sebagai berikut:

H2 : Kompetensi pengguna berpengaruh positif pada kinerja sistem informasi akuntansi.

Pelatihan dan pendidikan pengguna sistem informasi akuntansi tentu saja akan membantu pengguna sistem dalam keterlibatannya mengoperasikan sistem informasi akuntansi tersebut, sehingga dengan diadakannya program pelatihan dan pendidikan bagi pengguna sistem informasi akuntansi akan meningkatkan kualitas dari penggunaan sistem tersebut sehingga akan berpengaruh terhadap kinerja SIA. Widiastuti (2015) menjelaskan bahwa Dengan keberadaan sistem informasi akuntansi berbasis komputer, maka dibutuhkan juga sumber daya manusia yang terampil dalam bidang keuangan dan teknologi computer, maka Perusahaan berkewajiban untuk menyiapkan sumber daya manusia yang memadai dengan memberikan pelatihan di bidang keuangan dan teknologi computer (software). Berdasarkan penjelasan tersebut dapat disimpulkan bahwa guna menyiapkan sumber daya manusia yang handal dan terampil dalam menggunakan sistem yang terkomputerisasi sangat dibutuhkan adanya pendidikan dan pelatihan terkait sistem yang digunakan. Widiantari dan Mertha (2018) memperoleh hasil penelitian yaitu teknologi informasi dan kemampuan pemakai berpengaruh positif dan signifikan pada kinerja SIA, pendidikan dan pelatihan mampu memoderasi pengaruh teknologi informasi pada kinerja SIA, namun pendidikan dan pelatihan tidak mampu memoderasi pengaruh kemampuan pemakai pada kinerja SIA di BPR Kabupaten Klungkung. Berdasarkan penelitian-penelitian terdahulu maka, hipotesis tiga dinyatakan sebagai berikut:

H3 : Pendidikan dan pelatihan memperkuat pengaruh sistem komputerisasi pada kinerja sistem informasi akuntansi.

Program pendidikan dan pelatihan bagi pengguna dapat meningkatkan kemampuan untuk mengidentifikasi persyaratan informasi mereka, kesungguhan serta keterbatasan Sistem Informasi Akuntansi sehingga adanya program pendidikan dan pelatihan pengguna dapat meningkatkan kinerja SIA. Syintia (2017) menemukan bahwa kinerja sistem informasi akuntansi akan lebih baik jika suatu perusahaan mengadakan program pelatihan dan pendidikan untuk pengguna sistem informasi akuntansi. Hasil dari penelitian yang dilakukan oleh Kameswara (2013) menyatakan bahwa pelatihan dan pendidikan pengguna berpengaruh signifikan terhadap kinerja sistem informasi akuntansi yang diukur dengan kepuasan pengguna pada restoran waralaba asing di Kota Denpasar. Abhimantara dan Suryanawa (2016) juga mendapatkan hasil yang sama yaitu pelatihan dan pendidikan pengguna berpengaruh tehadap kinerja sistem informasi akuntansi.

$$
\text { Wilayanti dan Dharmadiaksa }
$$

(2016) menunjukkan hasil penelitian yaitu keterlibatan dan kemampuan teknik personal berpengaruh pada efektivitas penggunaan SIA. Hasil penelitian ini juga menunjukan bahwa pendidikan dan pelatihan memoderasi pengaruh keterlibatan dan kemampuan teknik personal pada efektivitas penggunaan SIA. Suartika dan Widhiyani (2017) memperoleh hasil penelitian yaitu kemampuan teknik personal berpengaruh positif pada efektivitas penggunaan sistem informasi akuntansi, pendidikan dan pelatihan memperkuat pengaruh kemampuan teknik personal pada efektivitas penggunaan sistem informasi 
akuntansi. Hasil berbeda diperoleh Widiantari dan Mertha (2018) yang mendapatkan hasil penelitian yaitu pendidikan dan pelatihan tidak mampu memoderasi pengaruh kemampuan pemakai pada kinerja SIA di BPR Kabupaten Klungkung. Berdasarkan uraian diatas, maka hipotesis empat dinyatakan sebagai berikut:

H4 : Pendidikan dan pelatihan memperkuat pengaruh kompetensi pengguna pada kinerja sistem informasi akuntansi.

\section{METODE PENELITIAN}

Penelitian ini menggunakan pendekatan kuantitatif yang berbentuk asosiatif. Penelitian ini menjelaskan tentang Pengaruh Sistem Komputerisasi dan Kompetensi Pengguna Pada Kinerja Sistem Informasi Akuntansi dengan Pendidikan dan Pelatihan Sebagai Pemoderasi. Penelitian ini dilakukan di Bapenda Provinsi Bali, yang beralamat di Jalan Tjok Agung Tresna No. 14 renon Denpasar. Objek penelitian dalam penelitian ini adalah variabel-variabel yang dapat memengaruhi kinerja sistem informasi akuntansi, yaitu : Sistem Komputerisasi, Kompetensi Pengguna, serta pendidikan dan pelatihan. Populasi dalam penelitian ini adalah seluruh pengguna SIA di Bapenda Provinsi Bali yang berjumlah 42 pegawai. Metode penentuan sampel yang digunakan dalam penelitian ini adalah non probability sampling dengan teknik sampling jenuh merupakan teknik penentuan sampel bila semua anggota populasi digunakan sebagai sampel, maka jumlah sampel dalam penelitian ini sebanyak 42 responden.

Metode pengumpulan data pada penelitian ini menggunakan metode survey denganteknikpengumpulan data menggunakan kuesioner. Kuesioner yang disebarkan berupa daftar pernyataan kepada responden mengenai sistem komputerisasi, kompetensi pengguna, pendidikan dan pelatihan serta kinerja sistem informasi akuntansi. Hasil jawaban tersebut kemudian diukur dengan menggunakan skala likert 4 poin. Teknik analisis data pada penelitian ini adalah Moderated Regression Analysis (MRA) yang dihitung menggunakan program SPSS yang sebelumnya dilakukan analisis Method Successive of Internal (MSI) untuk menstransformasikan data ordinal kuesioner jawaban responden menjadi data interval. Pengujian dapat dilakukan apabila model dari penelitian ini telah memenuhi syarat yaitu data harus, tidak mengandung heteroskedastisitas dan berdistribusi normal (uji asumsi klasik). Pengujian selanjutnya, yaitu uji statistic deskriptif, uji kelayakan model (Uji F) uji koefisien determinasi $\left(\mathrm{R}^{2}\right)$. setelah itu MRA, uji hipotesis (Uji t). Model regresi moderasi dalam penelitian ini dapat ditunjukkan dengan persamaan berikut.

$Y=a+\beta 1 X 1+\beta 2 X 2+\beta 3 M+\beta 4 X 1 . M+$ $\beta 5 \times 2 . M+e$

Keterangan :

$\mathrm{Y}=$ Kinerja Sistem Informasi Akuntansi

$\mathrm{X} 1=$ Sistem Komputerisasi

$\mathrm{X} 2$ = Kompetensi Pemakai

$\mathrm{M}=$ Pendidikan dan Pelatihan

a $=$ Konstanta

$\beta=$ Koefisien Regresi

\section{HASIL DAN PEMBAHASAN}

Pengumpulan data dilakukan melalui penyebaran kuesioner kepada pegawai Bapenda Provinsi Bali. Penyebaran kuesioner hingga semua kuesioner terjawab dan terkumpul kembali pada penelitian ini menghabiskan waktu selama 5 hari yaitu mulai tangal 3 September sampai 7 September 2018. Distribusi kuesioner beserta tingkat pengembalian kuesioner yang dapat diolah disajikan dalam Tabel 1 sebagai berkut.

Berdasarkan Tabel 1 dapat dijelaskan bahwa kuesioner yang disebar sebanyak 42 buah dengan tingkat pengembalian 100\% sehingga total kuesioner yang digunakan sebanyak 42 buah.

Statistik deskriptif bertujuan untuk memberikan informasi mengenai karakteristik variabel - variabel penelitian yaitu jumlah amata nilai minimum, nilai maksimum, nilai mean, dan standar deviasi. Untuk mengukur nilai sentral dari distribusi data dapat dilakukan dengan pengukuran rata - rata (mean) sedangkan standar deviasi merpakan perbedaan nilai data yang diteliti dengan nilai rata - ratanya. Hasil statistik deskriptif dapat 
Tabel 1.

Rincian Pengiriman dan Pengembalian Kuesioner

\begin{tabular}{lc}
\hline \multicolumn{1}{c}{ Keterangan } & Jumlah \\
\hline Kuesioner yang disebar & 42 \\
Kuesioner yang tidak kembali & - \\
Kuesioner yang dikembalikan & 42 \\
Kuesioner yang digunakan & 42 \\
\hline Tingkat Pengembalian (Respons rate) & $100 \%$ \\
Kuesioner yang dikembalikan x 100\% & \\
Kuesioner yang dikirim & $100 \%$ \\
\hline $\begin{array}{l}\text { Tingkat Pengembalian yang digunakan (useable response rate) } \\
\text { Kuesioner yang diolah x 100\% }\end{array}$ \\
$\begin{array}{l}\text { Kuesioner yang dikirm } \\
\text { Sumber: Data diolah, 2018 }\end{array}$
\end{tabular}

Tabel 2.

Hasil Statistik Deskriptif Variabel Penelitian

\begin{tabular}{lccccc}
\hline & N & Minimum & Maximum & Mean & Std. Deviation \\
\hline Sistem Komputerisasi & 42 & 2,25 & 3,92 & 3,07 & 0,398 \\
Kompetensi Pengguna & 42 & 1,67 & 4,00 & 3,10 & 0,563 \\
Pendidikan dan Pelatihan & 42 & 2,00 & 4,00 & 3,17 & 0,523 \\
Kinerja SIA & 42 & 2,13 & 3,75 & 3,07 & 0,424 \\
Valid N (listwise) & 42 & & & & \\
\hline
\end{tabular}

Sumber : Data diolah, 2018

Tabel 3.

Kriteria Pengukuran

\begin{tabular}{cc}
\hline Nilai Skor & Kriteria Variabel Sistem komputerisasi \\
\hline $1,00-1,75$ & Sangat Tidak Baik \\
$1,76-2,50$ & Tidak Baik \\
$2,51-3,25$ & Baik \\
$3,26-4,00$ & Sangat Baik \\
\hline
\end{tabular}

dilihat pada Tabel 2 berikut.

Berdasarkan hasil uji statistik deskriptif pada Tabel 2 dapat diketahui bahwa total sampel yang digunakan adalah sebanyak 42 orang responden.

Hasil uji statistik variabel sistem komputerisasi pada Tabel 2 memiliki nilai minimum sebesar 2,25 dan nilai maksimum sebesar 3,92. Variabel sistem komputerisasi yang diukur dengan 12 item pernyataan dengan bantuan skala likert 4 poin memiliki nilai rata-rata sebesar 3,07. Rentang kriteria untuk variabel sistem komputerisasi adalah sebagai berikut.

Nilai Interval : Skor maksimum Skor minimun $=4-1=3$
Range : $\frac{\text { Nilai Interval }}{\text { Jumlah kelas }}=\frac{3}{4}=0,75$

Skor pada penelitian ini memiliki nilai tertinggi maksimal 4 dan terendah minimal 1 , sehingga dapat disusun kriteria pengukuran yang dapat dilihat pada Tabel 3 sebagai berikut.

Nilai rata-rata variabel sistem komputerisasi sebesar 3,07 berada pada kriteria baik yaitu pada rentang nilai 2,51-3,25, maka dapat dikatakan bahwa Bapenda Provinsi Bali sudah memiliki sistem komputerisasi yang baik. Nilai standar deviasi variabel sistem komputerisasi sebesar 0,398. Hal ini berarti nilai ini lebih rendah dibandingkan dengan nilai rata-rata, yang artinya sebaran data terkait 
Tabel 1.

Rincian Pengiriman dan Pengembalian Kuesioner

\begin{tabular}{lc}
\hline & Unstandardized Residual \\
\hline $\mathrm{N}$ & 42 \\
Kolmogorov-Smirnov Z & 0,756 \\
Asymp. Sig. (2-tailed) & 0,618 \\
\hline
\end{tabular}

Sumber : Data diolah, 2018

Tabel 4.

Hasil Uji Heteroskedastisitas

\begin{tabular}{lccl}
\hline No & Variabel Bebas & Signifikansi & Keterangan \\
\hline 1 & Sistem Komputerisasi (X1) & 0,961 & Bebas heteros \\
2 & Kompetensi Pengguna (X2) & 0,518 & Bebas heteros \\
3 & Pendidikan dan Pelatihan (M) & 0,655 & Bebas heteros \\
4 & X1,M & 0,389 & Bebas heteros \\
5 & $\mathrm{X} 2, \mathrm{M}$ & 0,777 & Bebas heteros \\
\hline
\end{tabular}

dengan sistem komputerisasi sudah merata.

Hasil uji statistik variabel kompetensi pengguna pada Tabel 2 memiliki nilai minimum sebesar 1,67 dan nilai maksimum sebesar 4,00. Variabel kompetensi pengguna yang diukur dengan 3 item pernyataan dengan bantuan skala likert 4 memiliki nilai ratarata sebesar 3,10. Rentang kriteria untuk variabel kompetensi pengguna adalah 0,75. Nilai rata-rata variabel kompetensi pengguna sebesar 3,10 berada pada kriteria tinggi yaitu pada rentang nilai 2,51-3,25, maka dapat dikatakan bahwa pengguna sistem informasi akuntansi pada Bapenda Provinsi Bali sudah memiliki kompetensi yang tinggi. Nilai standar deviasi variabel kompetensi pengguna sebesar 0,563. Hal ini berarti nilai ini lebih rendah dibandingkan dengan nilai rata-rata, yang artinya sebaran data terkait kompetensi pengguna sudah merata.

Hasil uji statistik variabel pendidikan dan pelatihan pada Tabel 2 memiliki nilai minimum sebesar 2,00 dan nilai maksimum sebesar 4,00. Variabel pendidikan dan pelatihan yang diukur dengan 5 item pernyataan dengan bantuan skala likert 4 memiliki nilai rata-rata sebesar 3,17. Rentang kriteria untuk variabel pendidikan dan pelatihan adalah 0,75 . Nilai rata-rata variabel pendidikan dan pelatihan sebesar 3,17 berada pada kriteria baik yaitu pada rentang nilai 2,51-3,25, maka dapat dikatakan bahwa Bapenda Provinsi Bali sudah memberikan pendidikan dan pelatihan yang baik kepada pegawainya. Nilai standar deviasi variabel pendidikan dan pelatihan sebesar 0,523 . Hal ini berarti nilai ini lebih rendah dibandingkan dengan nilai rata-rata, yang artinya sebaran data terkait sudah merata.

Hasil uji statistik variabel kinerja sistem informasi akuntansi pada Tabel 2 memiliki nilai minimum sebesar 2,13 dan nilai maksimum sebesar 3,75. Variabel kinerja sistem informasi akuntansi yang diukur dengan 8 item pernyataan dengan bantuan skala likert 4 poin memiliki nilai rata-rata sebesar 3,07. Rentang kriteria untuk variabel kinerja sistem informasi akuntansi adalah 0,75 . Nilai rata-rata variabel kinerja sistem informasi akuntansi sebesar 3,07 berada pada kriteria baik yaitu pada rentang nilai 2,513,25, maka dapat dikatakan bahwa Bapenda Provinsi Bali sudah memiliki kinerja Sistem Informasi Akuntansi yang baik. Nilai standar deviasi variabel kinerja sistem informasi akuntansi sebesar 0,424. Hal ini berarti nilai ini lebih rendah dibandingkan dengan nilai rata-rata, yang artinya sebaran data terkait sudah merata.

Uji normalitas bertujuan untuk mengetahui apakah residual dari model regresi yang dibuat berdistribusi normal atau tidak. Untuk menguji apakah data yang digunakan normal atau tidak dapat dilakukan dengan menggunakan uji Kolmogorov Sminarnov. 
Tabel 6.

Hasil Analisis Regresi Moderasi

\begin{tabular}{|c|c|c|c|c|c|}
\hline \multirow[t]{2}{*}{ Model } & \multicolumn{2}{|c|}{$\begin{array}{c}\text { Unstandardized } \\
\text { Coefficients }\end{array}$} & \multirow{2}{*}{$\begin{array}{c}\begin{array}{c}\text { Standardized } \\
\text { Coefficients }\end{array} \\
\text { Beta } \\
\end{array}$} & \multirow[b]{2}{*}{$\mathrm{t}$} & \multirow[b]{2}{*}{ Sig. } \\
\hline & $\mathrm{B}$ & Std. Error & & & \\
\hline (Constant) & $-0,053$ & 0,096 & & $-0,550$ & 0,586 \\
\hline Sistem Komputerisasi & 0,398 & 0,107 & 0,417 & 3,721 & 0,001 \\
\hline Kompetensi Pengguna & 0,366 & 0,107 & 0,397 & 3,430 & 0,002 \\
\hline Pendidikan dan Pelatihan & 0,124 & 0,108 & 0,115 & 1,139 & 0,262 \\
\hline $\mathrm{X} 1 . \mathrm{M}$ & 0,277 & 0,101 & 0,287 & 2,741 & 0,009 \\
\hline $\mathrm{X} 2 . \mathrm{M}$ & 0,104 & 0,102 & 0,105 & 1,018 & 0,316 \\
\hline R Square & & & & & 0,688 \\
\hline Adjusted R Square & & & & & 0,645 \\
\hline F Statistik & & & & & 15,892 \\
\hline Signifikansi & & & & & 0,000 \\
\hline
\end{tabular}

Apabila koefisien Asymp. Sig. (2-tailed) lebih besar dari 0,05 maka data tersebut dikatakan berdistribusi normal. Hasil uji normalitas dalam penelitian ini dapat dilihat pada Tabel 4 berikut.

Berdasarkan Tabel 4, dapat dilihat bahwa nilai Kolmogorov Smirnov sebesar 0,756, sedangkan nilai Asymp. Sig. (2-tailed) sebesar 0,618. Hasil tersebut mengindikasikan bahwa model persamaan regresi tersebut berdistribusi normal karena nilai Asymp. Sig. (2-tailed) 0,618 lebih besar dari nilai alpha 0,05 .

Hasil uji heteroskedastisitas ini bertujuan untuk mengetahui apakah dalam model regresi terjadi ketidaksamaan varians dari residual satu pengamatan ke pengamatan lain yang dilakukan dengan uji Glejser. Jika tidak ada satu pun variabel bebas yang berpengaruh signifikan terhadap nilai absolute residual atau nilai signifikansinya di atas 0,05 maka tidak mengandung gejala heteroskedastisitas.

Pada Tabel 5, dapat dilihat bahwa nilai signifikansi dari variabel sistem komputerisasi sebesar 0,961, kompetensi pengguna sebesar 0,518 , pendidikan dan pelatihan sebesar 0,655 , variabel interaksi X1.M sebesar 0,389 dan variabel interaksi X2.M sebesar 0,777. Nilai tersebut lebih besar dari 0,05 yang berarti tidak terdapat pengaruh antara variabel bebas terhadap absolute residual. Dengan demikian, model yang dibuat tidak mengandung gejala heteroskedastisitas.

Pengujian data dalam penelitian ini menggunakan teknik analisis regresi moderasi. Perhitungan koefisien regresi moderasi dilakukan dengan analisis regresi melalui software SPSS 18.0 for Windows, diperoleh hasil yang ditunjukan pada Tabel 6 berikut.

Berdasarkan hasil analisis regresi linier berganda seperti yang disajikan pada Tabel 6 tersebut, maka persamaan strukturalnya adalah sebagai berikut :

$Y=\beta_{1} X_{1}+\beta_{2} X_{2}+\beta_{3} M+\beta_{4} X_{1} \cdot M+\beta_{5} X_{2} \cdot M$ $+\mathrm{e}$

$\mathrm{Y}=0,398 \mathrm{X}_{1}+0,366 \mathrm{X}_{2}+0,124 \mathrm{M}+0,277$ $\mathrm{X}_{1} \cdot \mathrm{M}+0,104 \mathrm{X}_{2} \cdot \mathrm{M}+\mathrm{e}$

Nilai R Square model (Uji koefisien determinasi) pada tabel 6 uji analisis regresi moderasi sebesar 0,688 artinya 68,8 persen kinerja sistem informasi akuntansi dipengaruhi oleh sistem komputerisasi, kompetensi pengguna, pendidikan dan pelatihan, sedangkan 31,2 persen dijelaskan oleh variabel lain diluar model.

Hasil uji $\mathrm{F}$ ( $F$ test) pada tabel 6 menunjukkan bahwa nilai signifikansi $\mathrm{P}$ value 0,000 yang lebih kecil dari $\alpha=0,05$, ini berarti model yang digunakan pada penelitian ini adalah layak. Hasil ini memberikan makna bahwa seluruh variabel independen 
yaitu sistem komputerisasi, kompetensi pengguna, dan variabel interaksi antara sistem komputerisasi dengan kompetensi pengguna mampu memprediksi atau menjelaskan fenomena kinerja sistem informasi akuntansi di Bapenda provinsi Bali.

Berdasarkan hasil analisis pengaruh sistem komputerisasi pada kinerja sistem informasi akuntansi pada Tabel 6, diperoleh nilai signifikansi sebesar 0,001 dengan nilai koefisien regresi sebesar 0,398. Nilai Signifikansi $\quad 0,001<0,05$ mengindikasikan bahwa $\mathrm{H}_{0}$ ditolak dan $\mathrm{H}_{1}$ diterima, mempunyai arti bahwa sistem komputerisasi berpengaruh positif dan signifikan pada kinerja sistem informasi akuntansi di Bapenda Provinsi Bali. Hal ini berarti semakin baik pengaplikasian sistem informasi akuntansi yang terkomputerisasi, maka akan semakin meningkatkan kinerja sistem informasi akuntansi di Bapenda Provinsi Bali.

Hasil penelitian ini didukung oleh hasil penelitian yang dilakukan oleh Widiastuti (2015) dan Hasnidar (2016) yang mendapatkan hasil yaitu sistem informasi akuntansi berbasis komputer berpengaruh positif terhadap kualitas laporan keuangan pemerintah daerah. Hasil penelitian ini menunjukkan bahwa dengan menerapkan sistem informasi akuntansi yang efektif dan efisien, penerapan sistem pengendalian internal pemerintahan yang memiliki kompetensi dalam pengelolaan keuangan daerah serta penerapan akrual basis yang baik akan mampu meningkatkan kualitas laporan keuangan pemerintah daerah.

Berdasarkan hasil analisis pengaruh kompetensi pengguna pada kinerja sistem informasi akuntansi pada Tabel 6, diperoleh nilai signifikansi sebesar 0,002 dengan nilai koefisien regresi sebesar 0,366. Nilai Signifikansi $0,002<0,050$ mengindikasikan bahwa $\mathrm{H} 0$ ditolak dan $\mathrm{H} 2$ diterima, mempunyai arti bahwa kompetensi pengguna berpengaruh positif dan signifikan pada kinerja sistem informasi akuntansi di Bapenda Provinsi Bali. Hal ini berarti bahwa semakin baik kompetensi yang dimiliki oleh pegawai Bapenda Provinsi Bali dalam menggunakan sistem informasi akuntansi, maka akan semakin meningkatkan kinerja sistem informasi akuntansi di Bapenda Provinsi Bali.

Hasil penelitian ini sesuai dengan hasil penelitian yang dilakukan oleh Kharisma dan Juliarsa (2017), Suryawarman (2013), dan Yunita, dkk (2016) yang menemukan bahwa kompetensi pengguna berpengaruh signifikan terhadap kinerja sistem informasi akuntansi. Penelitian ini juga didukung dengan hasil penelitian dari Supriyati (2015), dan Astria, dkk (2017) yang mendapatkan hasil penelitian yaitu kompetensi user, keandalan software dan keandalan database secara simultan berpengaruh positif terhadap kualitas informasi akuntansi.

Berdasarkan hasil analisis pengaruh sistem komputerisasi pada kinerja sistem informasi akuntansi dengan pendidikan dan pelatihan sebagai variabel moderasi pada Tabel 5, diperoleh nilai signifikansi variabel moderasi $\left(\beta_{3}\right)$ pendidikan dan pelatihan sebesar 0,262 (non significant) dan nilai signifikan variabel interaksi antara sistem komputerisasi dan pendidikan dan pelatihan $\left(\beta_{4}\right)$ signifikan sebesar 0,009 , hal ini mengindikasikan variabel moderasi merupakan tipe moderasi murni (pure moderasi). Pure moderasi merupakan variabel yang memoderasi hubungan antara variabel prediktor dan variabel tergantung di mana variabel moderasi murni berinteraksi dengan variabel prediktor tanpa menjadi variabel prediktor.

Hasil analisis regresi moderasi menunjukkan bahwa nilai koefisien regresi sistem komputerisasi $\left(\beta_{1}\right)$ positif sebesar 0,398 dengan nilai signifikansi sebesar 0,001 dan nilai koefisien regresi variabel interaksi $\mathrm{X}_{1 . \mathrm{M}}\left(\beta_{4}\right)$ positif sebesar 0,277 dengan nilai signifikansi 0,009, maka variabel pendidikan dan pelatihan merupakan variabel moderasi yang memperkuat pengaruh sistem komputerisasi pada kinerja sistem informasi akuntansi di Bapenda Provinsi Bali.

Hasil analisis regresi moderasi dalam penelitian ini menunjukkan bahwa pendidikan dan pelatihan secara statistik mampu memoderasi pengaruh sistem komputerisasi terhadap kinerja sistem informasi akuntansi di Bapenda Provinsi Bali. Pada penelitian 
ini, pendidikan dan pelatihan memperkuat pengaruh sistem komputerisasi terhadap kinerja $\mathrm{SIA}\left(\mathrm{H}_{3}\right.$ diterima). Hal ini menunjukkan bahwa dengan adanya pemberian pendidikan dan pelatihan yang mendukung bagi pegawai, maka pengaruh positif kemampunan pengguna terhadap kinerja SIA akan semakin meningkat. Hasil penelitian ini didukung oleh temuan Widiastuti (2015), serta Widiantari dan Mertha (2018) yang memperoleh hasil penelitian yaitu pendidikan dan pelatihan mampu memoderasi pengaruh teknologi informasi pada kinerja SIA.

Berdasarkan hasil analisis pengaruh kompetensi pengguna pada kinerja sistem informasi akuntansi dengan pendidikan dan pelatihan sebagai variabel moderasi pada Tabel 6 , diperoleh nilai signifikansi variabel moderasi $\left(\beta_{3}\right)$ pendidikan dan pelatihan sebesar 0,262 (non significant) dan nilai signifikan variabel interaksi antara kompetensi pengguna dengan pendidikan dan pelatihan $\left(\beta_{5}\right)$ tidak signifikan dengan nilai sebesar 0,316 , hal ini mengindikasikan variabel moderasi merupakan tipe moderasi homologiser. Variabel ini tidak berinteraksi dengan variabel prediktor (kompetensi pengguna) dan tidak mempunyai hubungan yang signifikan dengan variabel tergantung (kinerja SIA), maka dapat disimpulkan bahwa variabel pendidikan dan pelatihan tidak mampu memoderasi pengaruh kompetensi pengguna pada kinerja sistem informasi akuntansi di Bapenda Provinsi Bali. Hal ini mengindikasikan bahwa karyawan yang bekerja di Bapenda Provinsi Bali sudah memiliki kemampuan dalam menggunakan komputer, sehingga dengan adanya pendidikan dan pelatihan bagi pemakai SIA tidak berpengaruh pada kinerja SIA.

\section{SIMPULAN DAN SARAN}

Berdasarkan hasil penelitian yang sudah diuraikan sebelumnya, simpulan yang dapat diperoleh penelitian ini adalah Sistem komputerisasi dan kompetensi pengguna berpengaruh positif dan signifikan pada kinerja sistem informasi akuntansi. Hal ini berarti bahwa semakin baik pengaplikasian sistem informasi akuntansi yang terkomputerisasi serta semakin baik kompetensi maka akan semakin meningkatkan kinerja sistem informasi akuntansi di Bapenda Provinsi Bali. Pendidikan dan pelatihan secara statistik mampu memoderasi pengaruh sistem komputerisasi terhadap kinerja sistem informasi akuntansi. Hal ini menunjukkan bahwa dengan seringnya memberikan pendidikan dan pelatihan kepada pegawai akan membuat sistem komputerisasi informasi akuntansi semakin efektif, sehingga membuat kinerja sistem informasi akuntansi di Bapenda Provinsi Bali juga semakin meningkat. Namun Pendidikan dan pelatihan secara statistik tidak mampu memoderasi pengaruh kompetensi pengguna terhadap kinerja sistem informasi akuntansi. Hal ini berarti bahwa pegawai yang bekerja di Bapenda Provinsi Bali sudah memiliki kemampuan dalam menggunakan komputer, maka dengan adanya pemberian pendidikan dan pelatihan kepada pengguna SIA yang sudah menjadi pegawai, tidak berpengaruh secara efisien pada kinerja sistem informasi akuntansi di Bapenda Provinsi Bali tersebut.

Saran yang dapat peneliti usulkan berdasarkan hasil penelitian dan simpulan yang telah diuraikan di atas adalah Bagi Bapenda Provinsi Bali Meskipun hasil dalam penelitian ini menunjukkan pendidikan dan pelatihan tidak memoderasi kemampuan pemakai pada kinerja SIA. Hal ini disebabkan karena pelatihan dan pendidikan yang diberikan tidak memberikan keahlian pada penguna, sehingga manfaat yang diperoleh dari adanya pelatihan dan pendidikan belum maksimal, maka Bapenda Provinsi Bali sebaiknya tetap memberikan dan meningkatkan kualitas pelatihan yang diberikan kepada pegawainya dengan lebih efektif, misalnya seperti memperkerjakan konsultan dari luar, menggunakan manual pelatihan, menggunakan kaset video presentasi, menggunakan seminarseminar pelatihan atau menggunakan intruksiintruksi tercetak.

Bagi peneliti selajutnya disarankan untuk menambahkan variabel bebas ataupun variabel moderasi lainnya untuk menunjang kompleksitisitas penelitian, misalnya 
menambahkan variabel dukungan manajemen atau variabel kepercayaan pengguna.

\section{REFERENSI}

Abhimantra, Wayan Purwa dan Suryanawa, I Ketut. 2016. Analisis Faktor-faktor yang Mempengaruhi Kinerja Sistem Informasi Akuntansi. E-Jurnal Akuntansi Universitas Udayana, 14(3), hal:1782-1809.

Arif. 2015. Analisis faktor-faktor yang mempengaruhi kinerja sistem informasi akuntansi (studi empiris pada dealer mobil yang ada di daerah Sukoharjo dan Surakarta). Naskah Publikasi. Universitas Muhammadiyah Surakarta.

Astria, I., E. Halimatusadiah. dan N. Nurhayati. 2017. Pengaruh Kompetensi Pengguna, dan Pengendalian Internal Terhadap Kualitas Sistem Informasi Akuntansi (Survey pada Bank Syariah di Kota Bandung). Jurnal Akuntansi. Universitas Islam Bandung.

Biwi, Arzia. 2015. Pengaruh Kapabilitas Personal dan Dukungan Manajemen Puncak terhadap Kinerja Sistem Informasi Akuntansi PT. Tirta Mumbul Jaya Abadi Singaraja. E-journal Universitas Pendidikan Ganesha. Vol. 3.1. 2015.

Bokhari, R. 2005. The Relationship Between System Usage and User Satisfaction: a meta-analysis. Journal of Enterprise Information Management.

Choe, Jong-Min. 1996. The Relationship Among Performance of Accounting Information Systems, Influence Factors and Evolution Level of Information Systems. Journal of Management Information Systems.

DeLone, W.H., and Ephraim R. Mclean. 1992. Information System Success: The
Quest for the Dependent Variable. Information System Research.

Devi, Ni Luh Nyoman Sherina dan Suartana, I Wayan. 2014. Analisis Technology Acceptance Model (TAM) Terhadap Penggunaan Sistem Informasi Di Nusa Dua Beach Hotel \& Spa. E-Jurnal Akuntansi Universitas Udayana.

Fong, Steve C.C.2014.Accounting Information Systems End-User Satisfaction: Evidence of Hong Kong Housing Authority. The International Technology Management Review. Vol.4. No. 1. Hal: 27-41.

Galang Rahadian Prabowo, A. M. 2014. Faktor-Faktor yang Mempengaruhi Kinerja Sistem Informasi Akuntansi. Accounting Analysis Journal, 3(1). Hal:1-9.

Gustiyan, Hary. 2014. Analisis Faktor-Faktor yang Mempengaruhi Kinerja Sistem Informasi Akuntansi Pada Bank Perkreditan rakyat (BPR) di Tanjung Pinang. Jurnal Universitas Maritim Raja Ali Haji Tanjungpinang.

Hendrickson, A. R. 2003. Human Resource Information Systems: Backbone Technology of Contemporary Human Resources. Journal of Labor Research, 24(3). Hal: 381-394

Hota, Jyotiranjan, Implementation of ERP SaaS Option for HRIS Reporting Practices. 2012. International Conference on Technology and Business Management, Dubai, March 26-28, 2012.

Ihsanti, Emilda. 2014. Pengaruh Kompetensi Sumber daya Manusia dan Penerapan Sistem Akuntansi Keuangan Daerah Terhadap Kualitas Laporan Keuangan Daerah. Jurnal Akuntansi. 2(3). Hal: 1-20 
Istianingsih dan Setyo H Wijanto. 2008. Pengaruh Kualitas Sistem Informasi, Perceived Usefulness, dan Kualitas Informasi Terhadap Kepuasan Pengguna Akhir Software Akuntansi. Simposium Nasional Akuntansi : Vol SNA XI.Pontianak.

Ives, B., M. H. Olson., dan J.J., Baroudi. 1983. The Measurement of User Informations Satisfaction. Communication of the ACM. October

Kharisma, Ida Ayu Mira., dan Gede Juliarsa. 2017. Pengaruh Keterlibatan Pemakai, Kemampuan Pemakai, Pelatihan Dan Pendidikan Pemakai Terhadap Kinerja Sistem Informasi Akuntansi. E-Jurnal Akuntansi Universitas Udayana Vol.19.3. Hal: 2527-2555

Kusumastuti, M.C. dan S. A. Irwandi. 2012. Investigasi empat faktor kontingensi sebagai variabel moderating terhadap partisipasi pemakai dan kepuasan pemakai dalam pengembangan sistem informasi. The Indonesian Accounting Review. Vol.2, No. 2. Hal: 139 - 150.

Liu, C., and Arnett, K.P. 2000. Exploring the factors associated with website success in the context of electronic commerce. Journal Information and Management. Vol. 38. Hal: 23- 33

Lomarga, Gloria Valentcia.2013. Menciptakan strategi kompetitif melalui fungsi system informasi SDM, Malang. Jurnal JIBEKA. Vol.7, No.3. Hal:11-16

Montazemy, A.R., 1988. Factors Affecting Information Satisfaction in The Context of The Small Business Environment. Journal MIS Quarterly. Vol. 12, No. 2 Hal: 239-256.

Napitulu, Ilham Hidayah. 2015. Antecedence of user satisfaction in management accounting information systems quality: user involvement and user competency (survey of indonesia manufacture company managers)". Politeknik Negeri Medan - Indonesia and Padjadjaran University. Jurnal IJABER. Vol. 13, No. 2. Hal: 561-577.

Pantano, Eleonora and Loredana Di Pietro. 2012. Understanding Consumer's Acceptance of Technology-Based Innovation in Retailing. Journal of Technology Management\&Innovation. 7(4). Hal:1-19

Perbarini, Ni Kadek Ayu dan Juliarsa, Gede. 2014. Analisis Faktor-Faktor Yang Mempengaruhi Kinerja Sistem Informasi Akuntansi Pada Lpd Di Kecamatan Denpasar Utara.E-Jurnal Akuntansi Universitas Udayana, 9(3). Hal:728-746.

Prabowo, Rizky. 2013.“Faktor-Faktor Yang Mempengaruhi Kinerja Sistem Informasi Akuntansi Di Bank Umum Kota Surakarta".JUPE UNS, vol. 2, No.1. Hal 119-130.

Rai, A., Lang, S.S. and Welker, R.B. 2002. Assessing the Validity of IS Success Models: An Empirical Test and Theoretical Analysis, Information System Research. Vol.13, No.1. Hal: 29-34.

Soegiharto. 2001. Influence Factors Affecting The Performance of Accounting Information System. Journal International of Business. Vol. III No. 2. Hal: 177-202.

Spencer, Lyle M. \& Signe M. Spencer. 1993. Competence Work: Model for Superior Performance. John Wiley and Sons, Inc.

Suartika, K.A. dan N.L.S. Widhiyani. 2017. Kemampuan Teknik Personal Pada Efektivitas Penggunaan Sistem Informasi Akuntansi dengan 
Pendidikan dan Pelatihan Sebagai

Pemoderasi. E-Jurnal Akuntansi

Universitas Udayana Vol.18.2.

Hal: 1485-1512.

Supriyati. 2015. Pengaruh Kompetensi User, Keandalan Software dan Keandalan Database Terhadap Kualitas Informasi Akuntansi (Survey Pada Perusahaan BUMN yang Menerapkan Sistem Informasi Akuntansi Berpusat di Kota Bandung). Majalah Ilmiah UNIKOM Vol.13 No. 1.

Surendran, Priyanka. 2012. Technology Acceptance Model: A Survey of Literature. International Journal of Business and Social Research (IJBSR), Vol. 2, No.4. August 2012.

Surya, Anak Agung Made dan I Made Sadha Suardikha. 2016. Faktor-Faktor Yang Berpengaruh Pada Kepuasan Pengguna Sistem Informasi Akuntansi Lembaga Perkreditan Desa Di Kecamatan Mengwi. E-Jurnal Akuntansi Universitas Udayana, 15(1). Hal: 317-348

Syintia, A.A.A Putri W. 2016. Pengaruh Dukungan Manajemen Puncak, Keterlibatan Pengguna Dalam Penerapan Sistem Dan Program Pelatihan Terhadap Kinerja Sistem Informasi Akuntansi Pada Bank Perkreditan Rakyat Di Kecamatan Kediri Tabanan. E-Jurnal Fakultas Akuntansi Universitas Udayana, 5(1), hal: 344-764

Tjhai, Fung Jen. 2002.“Faktor-Faktor Yang Mempengaruhi Kinerja Sistem Informasi Akuntansi".Jurnal Bisnis dan Akuntansi Vol. IV No. 2.
Vaughan. Paula.2001. System Implementation Success Factors; It's not just the Technology. Journal of The University of Colorado at Boulder.

Widiantari, N.M.S. dan M. Mertha. 2018. Pendidikan dan Pelatihan Memoderasi Pengaruh Teknologi Informasi dan Kemampuan Pemakai Pada Kinerja Sistem Informasi Akuntansi. E-Jurnal Akuntansi Universitas Udayana Vol.22.1. Hal: 804-830.

Widiastuti, I.2015. Sistem InformasiAkuntansi Berbasis Komputer. Bhirawa. Vol. 2. No. 2 edisi Desember.

Wilayanti, N.W. dan I.B. Dharmadiaksa. 2016. Keterlibatan dan Kemampuan Teknik Personal Pada Efektivitas Penggunaan Sistem Informasi Akuntansi. E-Jurnal Akuntansi Universitas Udayana. Vol.15.2. Hal: 1310-1337.

Wilkinson, Joseph W. 2000. Accounting Information System. Frouth Edition. United States New York : John Wiley and Sons Inc.

Yunita, W., N. Nurhayati. dan M. L. Oktaroza. 2016. Pengaruh Kompetensi Pengguna dan Gaya Kepemimpinan Terhadap Kinerja Sistem Informasi Akuntansi (Survei Perusahaan Asuransi Kota Bandung). Skripsi. Universitas Islam Bandung. 